\title{
Effects of Oxytetracycline Containing Feed on Pond Ecosystem and Health of Carp (Cyprinus carpio L.)
}

\author{
Z. SVOBODOVÁ ${ }^{1,2}$, E. SUDOVÁ ${ }^{2}$, L. NEPEJCHALOVÁ ${ }^{3}$, S. ČERVINKA ${ }^{4}$, B. VYKUSOVÁ ${ }^{2}$, \\ H. MODRÁ ${ }^{1}$, J. KOLÁŘOVÁ ${ }^{2}$, \\ ${ }^{1}$ University of Veterinary and Pharmaceutical Sciences Brno, Czech Republic \\ ${ }^{2}$ University of South Bohemia České Budějovice, Research Institute of Fish Culture and Hydrobiology \\ Vodňany, Czech Republic \\ ${ }^{3}$ Institute for State Control of Veterinary Biomedical and Medicaments, \\ Brno, Czech Republic \\ ${ }^{4}$ State Veterinary Institute České Budějovice, České Budějovice, \\ Czech Republic
}

Received June 30, 2006

Accepted September 5, 2006

\begin{abstract}
Svobodová Z., E. Sudová, L. Nepejchalová, S. Červinka, B. Vykusová, H. Modrá, J. Kolářová: Effects of Oxytetracycline Containing Feed on Pond Ecosystem and Health of Carp (Cyprinus carpio L.). Acta Vet. Brno 2006, 75: 571-577.

The aim of the present study was to assess the effects of medicated feed, Rupin Special gran. ad us. vet. with oxytetracyclini chloridum as active ingredient $\left(5 \mathrm{~g} \cdot \mathrm{kg}^{-1} \mathrm{feed}\right)$, on physical and chemical characteristics of a pond ecosystem and the health of carp of two age groups in a pilot operation. The medicated feed was administered in 8 doses $\left(15 \mathrm{~g} \cdot \mathrm{kg}^{-1}\right.$ live weight $)$. In the study, temperature, oxygen concentration, $\mathrm{pH}$, microbiological, hydrobiological and hydrochemical variables of pond water were monitored. The fish health assessment was based on clinical, pathological-morphological and haematological examinations of 80 individuals in total. The examinations were made before, during, immediately after and 15 days after the administration of medicated feed. No effects on water quality were found. An important histological change after the application of 8 doses was the loss of haematopoietic tissue from the spleen, and dystrophic changes in the renal duct epithelium. A decrease in leukocyte and lymphocyte counts and in total blood plasma protein concentrations $(P<0.05)$ were observed already after the $3^{\text {rd }}$ dose of Rupin Special. It follows from the results of the study that Rupin Special should be used in only 4 (exceptionally 6) doses, compared to the originally recommended 8 doses.
\end{abstract}

Fish treatment, haematology, histology, medicated feed

For the suppression and treatment of bacterial diseases in fish, an effective medication is required to which pathogenic microorganisms are sensitive. At present there are only two antibiotic preparations registered in the Czech Republic for application to fish. These are Flumiquil $50 \%$ plv. ad us. vet., a synthetic chinolon-based antibiotic with flumequin as an active ingredient, and Rupin Special gran. ad us vet., a tetracycline antibiotic with oxytetracycline $\left(5 \mathrm{~g} \cdot \mathrm{kg}^{-1}\right)$ as an active ingredient (Kolářová and Nepejchalová 2005).

Rupin Special is a broad-spectrum antibiotic with activity against the majority of grampositive and gram-negative bacteria. Vitamin A (retinoli acetas) is present in the preparation mainly to improve the condition and resistance of the fish. Saccharin (saccharinum) and anise oil (anisi etheroleum) are added as taste correcting agents to guarantee that the feed is readily accepted by fish. Stabilizers and coating materials prevent undesirable changes in the preparation during its distribution or storage. Wheat flour is used as the vehicle of the preparation and this also increases the feed's nutritional value.

Rupin Special is supplied in cylindrically shaped pellets about $3-4 \times 3-10 \mathrm{~mm}$ in size. The pellets are hard, and they soften when soaked in water, although they will retain their

Address for correspondence:

MVDr. Eliška Sudová

University of South Bohemia České Budějovice

Research Institute of Fish Culture and Hydrobiology

38925 Vodňany, Czech Republic
Phone: +420383382402

Fax: +420383 382396

E-mail: sudova@vurh.jcu.cz

http://www.vfu.cz/acta-vet/actavet.htm 
shape for several hours (Červinka et al. 1997). They disintegrate in water after 20 to 22 hours. A normal ration is $15 \mathrm{~g}$ per $\mathrm{kg}$ live weight of fish stock at the time of application per feeding. Application should be repeated at 2- to 3-day intervals (if water temperature is constantly above $20^{\circ} \mathrm{C}$, a 2-day interval is recommended). The preparation is administered 4 to 6 times. The pellets are administered p.o. at any period when fish are able to ingest food. The feeding technique should guarantee that the medicated pellets are all eaten by fish within 6 hours after application. The protection period is 378 degree days (An on y mous 2004).

Oxytetracycline has different effects on the fish immune system, depending on the species, size of fish, water temperature and the way of drug application (V an der Heijden et al. 1991). Serezli et al. (2005) found that the drug reduced the phagocytic activation of phagocytic cells in the blood of sea bream and stimulated gilthead sea bream's immune system by increasing the number of NBT- positive cells (nitroblue tetrazolium assay) i.e., the total leukocyte and total erythrocyte numbers. This result is in agreement with the findings of Anderson and Jeney (1992). Although negative side effects have been reported in some cases, oxytetracycline remains one of the most frequently used antibiotics in aquaculture ( Tafalla et al. 1999).

The aim of the present study was to assess the effects of the medicated feed on the physical, chemical and biological characteristics of a pond ecosystem and the health of carp (Cyprinus carpio L.).

\section{Materials and Methods}

\section{Experimental design}

One- to two-year-old carp $\left(\mathrm{K}_{1-2}\right)$ and two- to three-year-old carp $\left(\mathrm{K}_{2-3}\right)$ were used in a pilot study to test the medicated feed. Experiments were made in 2 ponds of 0.08 ha in size and an average depth of $0.7 \mathrm{~m}$, belonging to the University of South Bohemia. In the spring, 400 one-year-old carp $\left(\mathrm{K}_{1}\right)$ weighing $16 \mathrm{~kg}$ (average $40 \mathrm{~g}$ per individual) were stocked in one pond (No. 68) and 200 two-year-old carp $\left(\mathrm{K}_{2}\right)$ weighing $210 \mathrm{~kg}$ (average $1050 \mathrm{~g}$ per individual) in the other pond (No. 69). The experiment took place from 2 June to 16 July. The fish in the ponds were given 8 doses ( $15 \mathrm{~g}$ Rupin Special pelleted feed per $1 \mathrm{~kg}$ live weight of fish stock) every second day from June 4 to June 25. The monitoring and evaluation of the results focused on the examination of pond water and on fish health before, during, immediately after, and 15 days after the application of the Rupin Special medicated feed, using each time 10 fish from each pond. The timetable of the experiments is given in Table 1.

\section{Water tests}

Water temperature, $\mathrm{pH}$ and oxygen concentrations in the ponds were checked 3 times daily (at 7 am, 2 pm and $7 \mathrm{pm}$ ) from 2 June to 16 July with MultiLine P4, a combined pH meter and oximeter (WTW Company). From the three daily measurements, mean daily temperatures were calculated.

At three different sites, at the water inflow site, at the centre of the lateral wall, and at the water outflow site of each of the ponds, water samples were taken for microbiological examination. The samples were analyzed in the microbiology laboratory of the State Veterinary Institute in České Budejovice. The numbers of coliform, mesophilic and psychrophilic bacteria were determined according to Czech standard techniques (ČSN EN ISO 9308-1 Water Quality - Detection and Enumeration of Escherichia coli and coliform bacteria and in ČSN EN ISO 6222 Water Quality - Detection and Enumeration of Culturable Micro-organisms).

As part of hydrobiological testing of the water, plankton and benthos samples were taken, according to Hrb áček et al. (1962).

Basic hydrochemical tests of water samples $\left(\mathrm{ANC}_{4,5} ; \mathrm{BNC}_{8,3} ; \mathrm{COD}_{\mathrm{Mn}} ; \mathrm{NH}_{4}^{+} ; \mathrm{NO}_{3}^{-} ; \mathrm{NO}_{2}^{-} ; \mathrm{PO}_{4}^{3-}\right)$ of the two ponds were made once weekly (methods according to Horák ová et al. 1986).

\section{Examination of fish}

Fish health assessment was based on clinical, pathological and histological examination of fish tissues during administration of Rupin Special. Haematological examinations were based on standardized methods for the haematological testing of fish (Svobodová et al. 1991). In the course of the tests of the Rupin Special feed, 40 specimens of carp fry $\mathrm{K}_{1-2}$ and 40 specimens of carp stock $\mathrm{K}_{2-3}$ were haematologically examined. The sampling timetable is given in Table 1. Blood samples were taken immediately after the carp were fished out of the pond, always at the same time between 8 and 9 am. Blood was withdrawn from the heart and stored in heparinized test tubes (50 IU heparin per $1 \mathrm{ml}$ blood). The blood indicators determined included red blood cell count (RBC), haematocrit $(\mathrm{PCV})$, haemoglobin concentration $(\mathrm{Hb})$, mean erythrocyte volume (MCV), erythrocyte haemoglobin $(\mathrm{MCH})$, mean colour concentration (MCHC), leukocyte count (Leuko) and the differential leukocyte count. Total protein (TP) of blood plasma was determined by refractometry. The results were processed by one-way analysis of variance (ANOVA, STATGRAPHIC software package). 
Table 1. The timetable of the study

\begin{tabular}{|c|c|c|c|c|c|}
\hline Date & $\begin{array}{l}\text { Rupin Special } \\
\text { application }\end{array}$ & $\begin{array}{l}\text { Blood sampling } \\
\text { and health tests/ } \\
\text { histological } \\
\text { examination }\end{array}$ & $\begin{array}{c}\text { Hydrochemical } \\
\text { water tests }\end{array}$ & $\begin{array}{c}\text { Hydrobiological } \\
\text { water tests }\end{array}$ & $\begin{array}{c}\text { Microbiological } \\
\text { water tests }\end{array}$ \\
\hline 2.6. & \multicolumn{5}{|l|}{ start of testing } \\
\hline 3.6. & & $+/ t$ & & + & \\
\hline 4. 6. & $1 .+$ & & + & & \\
\hline 5.6. & & & & & + \\
\hline 7.6. & $2 .+$ & & & & \\
\hline 10.6. & $3 .+$ & & & & \\
\hline 11.6. & & & & & + \\
\hline 12. 6. & & + & + & & \\
\hline 13.6. & 4.+ & & & & \\
\hline 14. 6. & & & & + & \\
\hline 16.6. & $5 .+$ & & & & \\
\hline 18. 6. & & & & & + \\
\hline 19.6. & $6 .+$ & & + & & \\
\hline 22.6. & 7.+ & & & & \\
\hline 25.6. & $8 .+$ & & + & & \\
\hline 27.6. & & $+/+$ & & + & + \\
\hline 1.7. & & & + & & \\
\hline 8.7. & & & + & & \\
\hline 10.7. & & $+/+$ & & & \\
\hline 16.7. & & & + & & \\
\hline
\end{tabular}

\section{Results and Discussion}

Water temperature, $\mathrm{pH}$, and oxygen concentrations

The values measured for these indicators were within the ranges characteristic for pond water at that time of the growing season (Fig. 1). During the trial (between 13 and 23 June), lower oxygen concentrations were found in the early hours of the day. The feeding regimen was adjusted to that situation (feeding at midday hours).
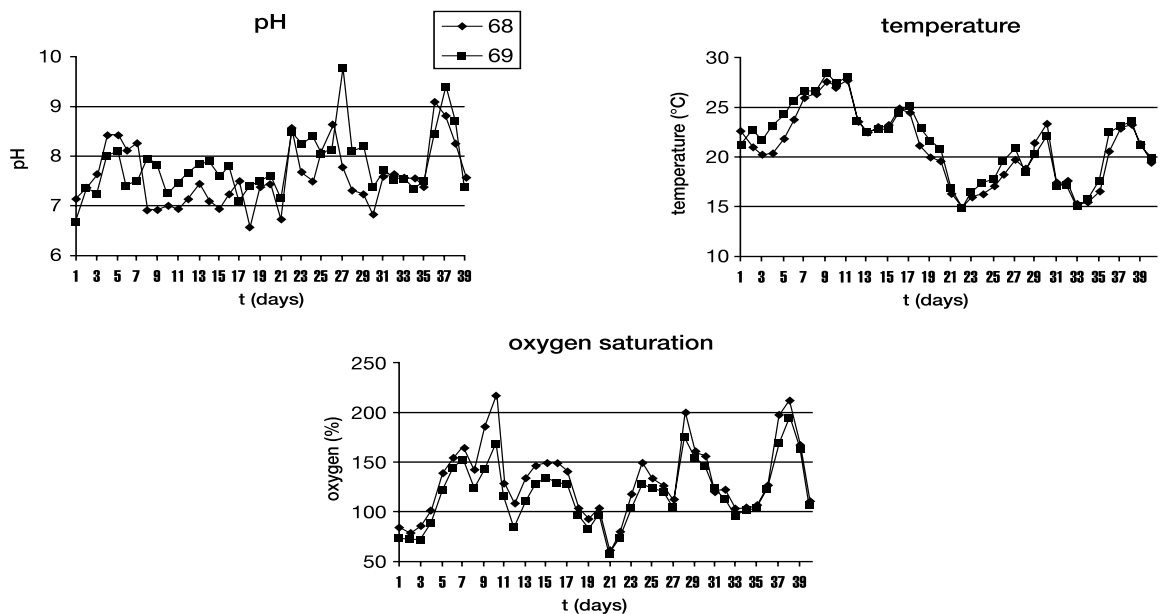

Fig. 1. The pH, temperature and oxygen values in water of ponds 68 and 69 during the testing period 


\section{Microbiological water tests}

The numbers of mesophilic or psychrophilic bacteria were similar at any time during the trial. The numbers of coliform bacteria were reduced, which might be explained as a natural development in a filled-up pond during the summer season (ponds were supplied with water, but had practically no outflow during the monitoring period). The effect of oxytetracycline cannot, however, be ruled out.

Hydrobiological water tests

Hydro-biological tests of water made before, during and after the feeding of Rupin Special showed that species representation and quantities of individual plankton and zoobenthos organisms were normal for the season and the feeding pressure of the fish stocks in the two ponds.

Hydrochemical water tests

Basic hydrochemical analysis of water $\left(\mathrm{ANC}_{4,5} ; \mathrm{BNC}_{8,3} ; \mathrm{COD}_{\mathrm{Mn}} ; \mathrm{NH}_{4}{ }^{+} ; \mathrm{NO}_{3}{ }^{-} ; \mathrm{NO}_{2}{ }^{-}\right.$; $\mathrm{PO}_{4}{ }^{3-}$ ) was made once a week in both ponds. The values measured for these indicators were within the ranges characteristic for pond water at that time of the vegetative period.

Fish health

Fish health examinations of were made before, during, immediately and 15 days after feeding Rupin Special pellets. No clinical symptoms of any of cyprinid fish diseases were found at any time during the trial. Pathological examinations showed $30 \%$ prevalence of tapeworm (Khawia sinensis) in the carp intestines.

Histological tests following the application of the last $\left(8^{\text {th }}\right)$ dose of the feed showed a marked decrease in haematopoiesis in the spleen, which was permeated with clusters of melanomacrophages. Diffuse cytoplasmatic vacuolization of the renal duct epithelium was found in the kidneys. These changes, which were more clearly manifested in $\mathrm{K}_{2-3}$ carp stock than in $\mathrm{K}_{1-2}$ carp stock, persisted until the last tests made three weeks after the last feeding Rupin Special.

Haematological fish tests

In carp of the $\mathrm{K}_{2-3}$ age group, a significant decrease $(P<0.05)$ in the $\mathrm{RBC}$, haematocrit $(\mathrm{PCV})$ and haemoglobin concentration $(\mathrm{Hb})$ were observed after the $3^{\text {rd }}$ to $8^{\text {th }}$ dose of Rupin Special. Two weeks after the trial, the haematological variables of red blood count monitored ( $\mathrm{RBC}$ and $\mathrm{Hb}$ ) were back to normal. The response of $\mathrm{K}_{1-2}$ carp to Rupin Special was less dramatic. The RBC remained practically unchanged throughout the trial period. A significant decrease of haematocrit values $(P<0.05)$ was found that persisted for at least 15 days after the end of the medicated feed application. Haemoglobin concentrations, which were gradually increasing throughout the trial period, markedly increased after the $8^{\text {th }}$ dose of medicated feed (Tables 2 and 3).

Table 2. Erythrocyte profile of carp $\left(\mathrm{K}_{1-2}\right)$ before, during and after Rupin Special application (groups with different alphabetic superscripts differ significantly at $P<0.05$ - ANOVA)

\begin{tabular}{|c|c|c|c|c|c|}
\hline \multirow[b]{2}{*}{ Indices } & \multirow[b]{2}{*}{ Units } & \multicolumn{4}{|c|}{ Sampling date } \\
\hline & & $\begin{array}{c}\text { before } \\
\text { 3. } 6 . \\
\text { mean } \pm \text { SD } \\
(n=10)\end{array}$ & $\begin{array}{c}\text { during } \\
12.6 . \\
\text { mean } \pm \text { SD } \\
(n=10)\end{array}$ & $\begin{array}{c}\text { immediately after } \\
27.6 . \\
\text { mean } \pm \text { SD } \\
(n=10)\end{array}$ & $\begin{array}{c}15 \text { days after } \\
10.7 \\
\text { mean } \pm \text { SD } \\
(n=10)\end{array}$ \\
\hline Body weight & $\mathrm{g}$ & $80.5 \pm 3.53 a$ & $117.0 \pm 5.69^{\mathrm{a}}$ & $135.5 \pm 9.41^{b}$ & $158.0 \pm 9.30^{c}$ \\
\hline $\mathrm{RBC}$ & $\mathrm{T} \cdot \mathrm{l}^{-1}$ & $1.36 \pm 0.069^{\mathrm{a}}$ & $1.36 \pm 0.075^{\mathrm{a}}$ & $1.40 \pm 0.072^{\mathrm{a}}$ & $1.44 \pm 0.043^{\mathrm{a}}$ \\
\hline $\mathrm{PCV}$ & $1 \cdot 1^{-1}$ & $0.44 \pm 0.010^{\mathrm{a}}$ & $0.39 \pm 0.007^{a}$ & $0.29 \pm 0.017^{b}$ & $0.30 \pm 0.008^{b}$ \\
\hline $\mathrm{Hb}$ & $\mathrm{g} \cdot \mathrm{l}^{-1}$ & $67.2 \pm 1.80^{\mathrm{a}}$ & $70.3 \pm 2.33^{a}$ & $85.6 \pm 3.07^{b}$ & $80.7 \pm 2.62^{b}$ \\
\hline $\mathrm{MCV}$ & $\mathrm{fl}$ & $332 \pm 14.0^{\mathrm{a}}$ & $296 \pm 13.3^{\mathrm{a}}$ & $212 \pm 11.9^{b}$ & $212 \pm 3.8^{b}$ \\
\hline $\mathrm{MCH}$ & pg & $50.2 \pm 1.90^{\mathrm{a}}$ & $53.0 \pm 3.08^{a}$ & $62.4 \pm 2.80^{\mathrm{b}}$ & $56.1 \pm 1.41^{\mathrm{ab}}$ \\
\hline $\mathrm{MCHC}$ & $\mathrm{g} \cdot \mathrm{l}^{-1}$ & $0.15 \pm 0.003^{\mathrm{a}}$ & $0.18 \pm 0.004^{\mathrm{a}}$ & $0.30 \pm 0.012^{b}$ & $0.27 \pm 0.006^{b}$ \\
\hline
\end{tabular}


Table 3. Erythrocyte profile of carp $\left(\mathrm{K}_{2-3}\right)$ before, during and after Rupin Special application (groups with different alphabetic superscripts differ significantly at $P<0.05$ - ANOVA)

\begin{tabular}{|c|c|c|c|c|c|}
\hline \multirow[b]{2}{*}{ Indices } & \multirow[b]{2}{*}{ Units } & \multicolumn{4}{|c|}{ Sampling date } \\
\hline & & $\begin{array}{c}\text { before } \\
3.6 . \\
\text { mean } \pm S D \\
(n=10)\end{array}$ & $\begin{array}{c}\text { during } \\
12.6 . \\
\text { mean } \pm \text { SD } \\
(n=10)\end{array}$ & $\begin{array}{c}\text { immediately after } \\
27.6 . \\
\text { mean } \pm \text { SD } \\
(n=10)\end{array}$ & $\begin{array}{c}15 \text { days after } \\
10.7 . \\
\text { mean } \pm \text { SD } \\
(n=10)\end{array}$ \\
\hline Body weight & g & $1023 \pm 71.9^{\mathrm{a}}$ & $1042 \pm 61.0^{\mathrm{a}}$ & $1218 \pm 96.1^{b}$ & $1233 \pm 115.4^{b}$ \\
\hline $\mathrm{RBC}$ & $\mathrm{T} \cdot 1^{-1}$ & $1.66 \pm 0.073^{\mathrm{a}}$ & $1.38 \pm 0.061^{\mathrm{a}}$ & $1.20 \pm 0.046^{\mathrm{b}}$ & $1.54 \pm 0.073^{\mathrm{a}}$ \\
\hline PCV & $1 \cdot 1^{-1}$ & $0.47 \pm 0.019^{a}$ & $0.39 \pm 0.016^{\mathrm{a}}$ & $0.31 \pm 0.010^{\mathrm{b}}$ & $0.32 \pm 0.010^{b}$ \\
\hline $\mathrm{Hb}$ & $\mathrm{g} \cdot \mathrm{l}^{-1}$ & $89.1 \pm 4.70^{\mathrm{a}}$ & $78.8 \pm 3.22^{\mathrm{ab}}$ & $74.2 \pm 3.11^{\mathrm{b}}$ & $88.9 \pm 2.24^{\mathrm{a}}$ \\
\hline $\mathrm{MCV}$ & $\mathrm{fl}$ & $278 \pm 4.3^{\mathrm{a}}$ & $288 \pm 11.0^{\mathrm{a}}$ & $258 \pm 15.0^{\mathrm{a}}$ & $209 \pm 7.8^{b}$ \\
\hline $\mathrm{MCH}$ & pg & $54.3 \pm 2.72^{\mathrm{a}}$ & $57.9 \pm 2.60^{\mathrm{ab}}$ & $62.6 \pm 2.60^{\mathrm{b}}$ & $58.7 \pm 2.30^{\mathrm{ab}}$ \\
\hline $\mathrm{MCHC}$ & $\mathrm{g} \cdot \mathrm{l}^{-1}$ & $0.19 \pm 0.011^{\mathrm{a}}$ & $0.20 \pm 0.010^{\mathrm{a}}$ & $0.24 \pm 0.008^{b}$ & $0.28 \pm 0.005^{\mathrm{c}}$ \\
\hline
\end{tabular}

A very clear response ocurred after the $3^{\text {rd }}$ dose of medicated feed in the form of a significant drop in the WBC count in both the $\mathrm{K}_{1-2}$ and the $\mathrm{K}_{2-3}$ carp. While the leukocyte counts of the $\mathrm{K}_{1-2}$ carp fry two weeks after the end of medicated feed administration were still significantly lower $(P<0.05)$ than values ascertained prior to the administration, the leukocyte count in $\mathrm{K}_{2-3}$ carp had returned to normal by that time. Changes in leukocyte counts correspond with lymphocytic changes $(r=0.9 \pm 4$; $P<0.01$ ). Absolute numbers of other leukocyte types (leukocytes of the myeloid line and monocytes) did not show statistically significant differences throughout the trial period in any of the groups (Tables 4 and 5). Neither did the percentage representation of individual leukocyte types in $\mathrm{K}_{1-2}$ and $\mathrm{K}_{2-3}$ carp differ significantly throughout the testing period.

Table 4. Leukocyte profile and TP of carp $\left(\mathrm{K}_{1-2}\right)$ before, during and after Rupin Special application (groups with different alphabetic superscripts differ significantly at $P<0.05$ - ANOVA)

\begin{tabular}{|c|c|c|c|c|c|}
\hline \multirow[b]{2}{*}{ Indices } & \multirow[b]{2}{*}{ Units } & \multicolumn{4}{|c|}{ Sampling date } \\
\hline & & $\begin{array}{c}\text { before } \\
3.6 . \\
\text { mean } \pm \text { SD } \\
(n=10)\end{array}$ & $\begin{array}{c}\text { during } \\
12.6 . \\
\text { mean } \pm \text { SD } \\
(n=10)\end{array}$ & $\begin{array}{c}\text { immediately after } \\
27.6 . \\
\text { mean } \pm \text { SD } \\
(n=10)\end{array}$ & $\begin{array}{c}15 \text { days after } \\
10.7 . \\
\text { mean } \pm \text { SD } \\
(n=10)\end{array}$ \\
\hline Body weight & $\mathrm{g}$ & $80.5 \pm 3.5^{\mathrm{a}}$ & $117.0 \pm 5.7^{\mathrm{a}}$ & $135.5 \pm 9.5^{b}$ & $158.0 \pm 9.3^{b}$ \\
\hline Leukocytes & $\mathrm{G} \cdot \mathrm{l}^{-1}$ & $227.5 \pm 16.25^{\mathrm{a}}$ & $130.5 \pm 16.40^{b}$ & - & $134.1 \pm 10.37^{b}$ \\
\hline Lymphocytes & $\mathrm{G} \cdot \mathrm{l}^{-1}$ & $210.9 \pm 19.05^{\mathrm{a}}$ & $95.2 \pm 21.57^{b}$ & - & $125.4 \pm 9.34^{\mathrm{c}}$ \\
\hline Monocytes & $\mathrm{G} \cdot \mathrm{l}^{-1}$ & $0.27 \pm 0.180^{\mathrm{a}}$ & $0.21 \pm 0.152 \mathrm{a}$ & - & $0.26 \pm 0.132^{\mathrm{a}}$ \\
\hline Metamyelocytes & $\mathrm{G} \cdot \mathrm{l}^{-1}$ & $1.38 \pm 0.501^{\mathrm{a}}$ & $0.66 \pm 0.247^{\mathrm{a}}$ & - & $0.71 \pm 0.199^{\mathrm{a}}$ \\
\hline Myelocytes & $\mathrm{G} \cdot \mathrm{l}^{-1}$ & $0.19 \pm 0.129^{a}$ & $0.92 \pm 0.358^{a}$ & - & $1.03 \pm 0.307^{\mathrm{a}}$ \\
\hline $\begin{array}{l}\text { Band } \\
\text { neutrophils }\end{array}$ & $\mathrm{G} \cdot \mathrm{l}^{-1}$ & $0.45 \pm 0.301^{\mathrm{a}}$ & $0.06 \pm 0.058^{\mathrm{a}}$ & - & $0.45 \pm 204^{\mathrm{a}}$ \\
\hline $\begin{array}{l}\text { Segmented } \\
\text { neutrophils }\end{array}$ & $\mathrm{G} \cdot 1^{-1}$ & $2.53 \pm 0.567^{\mathrm{a}}$ & $0.60 \pm 0.220^{\mathrm{a}}$ & - & $2.04 \pm 0.574^{\mathrm{a}}$ \\
\hline Plasmatic cells & $\mathrm{G} \cdot \mathrm{l}^{-1}$ & $1.62 \pm 0.581^{\mathrm{a}}$ & $2.28 \pm 0.740^{\mathrm{a}}$ & - & $3.52 \pm 0.933^{\mathrm{a}}$ \\
\hline $\mathrm{TP}$ & $g \cdot l^{-1}$ & $8.32 \pm 0.732^{\mathrm{a}}$ & $3.17 \pm 1.102^{b}$ & $11.28 \pm 0.730^{c}$ & $8.73 \pm 0.710^{\mathrm{a}}$ \\
\hline
\end{tabular}

Carp of both categories showed a significant decrease $(P<0.05)$ of total protein in blood plasma concentrations after the $3^{\text {rd }}$ dose. This change, however, was reversible. This biochemical indicator demonstrated a significant jump $(P<0.05)$ to original values after the administration of the $8^{\text {th }}$ dose. 
Table 5. Leukocyte profile and TP of carp $\left(\mathrm{K}_{2-3}\right)$ before, during and after Rupin Special application (groups with different alphabetic superscripts differ significantly at $P<0.05$ - ANOVA)

\begin{tabular}{|c|c|c|c|c|c|}
\hline \multirow[b]{2}{*}{ Indices } & \multirow[b]{2}{*}{ Units } & \multicolumn{4}{|c|}{ Sampling date } \\
\hline & & $\begin{array}{c}\text { before } \\
3.6 . \\
\text { mean } \pm \text { SD } \\
(n=10)\end{array}$ & $\begin{array}{c}\text { during } \\
12.6 . \\
\text { mean } \pm \text { SD } \\
(\mathrm{n}=10)\end{array}$ & $\begin{array}{c}\text { immediately after } \\
27.6 . \\
\text { mean } \pm \text { SD } \\
(n=10)\end{array}$ & $\begin{array}{c}15 \text { days after } \\
10.7 . \\
\text { mean } \pm \text { SD } \\
(n=10)\end{array}$ \\
\hline Body weight & $\mathrm{g}$ & $1023 \pm 71.9^{\mathrm{a}}$ & $1042 \pm 61.0^{\mathrm{a}}$ & $1218 \pm 96.1^{b}$ & $1233 \pm 115.4^{b}$ \\
\hline Leukocytes & $\mathrm{G} \cdot \mathrm{l}^{-1}$ & $115.3 \pm 9.60^{\mathrm{a}}$ & $57.5 \pm 5.66^{b}$ & - & $124.1 \pm 10.17^{\mathrm{a}}$ \\
\hline Lymphocytes & $\mathrm{G} \cdot \mathrm{l}^{-1}$ & $111.9 \pm 9.38^{\mathrm{a}}$ & $57.4 \pm 6.72^{b}$ & - & $116.4 \pm 12.60^{\mathrm{a}}$ \\
\hline Monocytes & $\mathrm{G} \cdot 1-1$ & $0.07 \pm 0.066^{\mathrm{a}}$ & $0.18 \pm 0.099^{\mathrm{a}}$ & - & $0.28 \pm 0.126^{\mathrm{a}}$ \\
\hline Metamyelocytes & $\mathrm{G} \cdot \mathrm{l}^{-1}$ & $0.67 \pm 0.181^{\mathrm{a}}$ & $0.31 \pm 0.108^{a}$ & - & $1.14 \pm 0.324^{\mathrm{a}}$ \\
\hline Myelocytes & $\mathrm{G} \cdot \mathrm{l}^{-1}$ & $0.28 \pm 0.117^{\mathrm{a}}$ & $0.52 \pm 0.161^{\mathrm{a}}$ & - & $0.67 \pm 0.232^{\mathrm{a}}$ \\
\hline Band neutrophils & $\mathrm{G} \cdot \mathrm{l}^{-1}$ & $0.14 \pm 0.072^{\mathrm{a}}$ & $0.38 \pm 0.126^{\mathrm{a}}$ & - & $0.64 \pm 0.535^{\mathrm{a}}$ \\
\hline $\begin{array}{l}\text { Segmented } \\
\text { neutrophils }\end{array}$ & $\mathrm{G} \cdot 1-1$ & $1.09 \pm 0.272^{\mathrm{a}}$ & $0.76 \pm 0.170^{\mathrm{a}}$ & - & $1.48 \pm 0.214^{\mathrm{a}}$ \\
\hline Plasmatic cells & $\mathrm{G} \cdot \mathrm{l}^{-1}$ & $1.20 \pm 0.548^{\mathrm{a}}$ & $0.27 \pm 0.067^{\mathrm{a}}$ & - & $1.95 \pm 0.570^{\mathrm{a}}$ \\
\hline $\mathrm{TP}$ & $\mathrm{g} \cdot \mathrm{l}^{-1}$ & $24.8 \pm 1.63^{\mathrm{a}}$ & $14.8 \pm 1.20^{b}$ & $19.7 \pm 1.11^{\mathrm{ab}}$ & $20.6 \pm 1.11^{\mathrm{ab}}$ \\
\hline
\end{tabular}

Oxytetracycline-based medicated feed had negative effects on the monitored haematological indices and on the haematopoietic tissue. Authors of a study on the effects of intramuscularly administered oxytetracycline (OTC) on tench (Tinca tinca) noted that the main lesions worth mentioning were located in the liver and kidneys. At 24 hours after OTC administration, fatty degeneration was observed in the liver. Afterwards it progressively diminished. The main tissue damage was found in the kidneys: initially, necrosis of the tubular epithelium was detected and on day 7 a severe necrosis of the haematopoietic renal tissue was observed (Soler et al. 1996).

We found that the negative response to oxytetracycline was more pronounced in older $\left(\mathrm{K}_{2-3}\right)$ carp than in juvenile carp $\left(\mathrm{K}_{1-2}\right)$. We believe that this was caused by differences in feed uptake. $\mathrm{K}_{2-3}$ carp immediately took the medicated feed when it was brought to the feeding site and in their digestive tracts mainly remains of Rupin Special were found during autopsy. $\mathrm{K}_{1-2}$ fish, on the other hand, preferred natural trophic conditions in their pond, and were less eager to take the medicated feed. During autopsy, large quantities of semi-digested items of their natural diet were found in their digestive tract together with remains of the medicated feed.

From our observation on leukocytic and lymphocytic changes we conclude that oxytetracycline has immunosuppressive effects. This has also been concluded by Rijkers et al. (1980) in carp and by Kou (1984) in eels. These authors observed the effect of oxytetracycline upon humoral immunity after injection administration. Lunden et al. (1998) noted that oxytetracycline significantly suppresses the production of antibodies and the numbers of circulating white cells (particularly lymphocytes) in rainbow trout (Oncorhynchus mykiss). Grondel et al. (1985) investigated the effects of oxytetracycycline on carp in vitro. They demonstrated relationships between the dose size and leukocytes activity. Low concentrations of oxytetracycline delayed the mitogenic response of phytohaemagglutinin-stimulated pronephric leukocytes in a dose-dependent manner, but did not reduce it.

\section{Vliv krmiva s obsahem oxytetracyklinu na rybniční ekosystém a zdravotní stav kaprů}

Cílem předkládané práce bylo posoudit vliv medikovaného krmiva Rupin Special gran. ad us. vet. s účinnou látkou oxytetracyclini chloridum $\left(5 \mathrm{~g} \cdot \mathrm{kg}^{-1} \mathrm{krmiva}\right)$ na fyzikální a chemické vlastnosti rybničního ekosystému a na zdravotní stav kaprů dvou věkových 
kategorií v poloprovozních podmínkách. Medikované krmivo bylo aplikováno v 8 dávkách $\left(15 \mathrm{~g} \cdot \mathrm{kg}^{-1}\right.$ živé hmotnosti). V průběhu sledování byla monitorována teplota, koncentrace kyslíku a pH vody, dále byla prováděna mikrobiologická, hydrobiologická a hydrochemická vyšetření rybniční vody. Zdravotní stav ryb byl posuzován na základě klinického, patologicko-morfologického a hematologického vyšetření 80 jedinců. Tato vyšetření byla provedena před aplikací, v průběhu aplikace, bezprostředně a 15 dní po aplikaci medikovaného krmiva. Nebyl zjištěn vliv aplikace na kvalitu vody a její přirozené osídlení nižšími organismy. Významnou histologickou změnou po aplikaci 8 dávek byl úbytek krvetvorné tkáně ve slezině a dystrofické změny epitelu ledvinových kanálků. Signifikantní pokles celkového počtu leukocytů, lymfocytů a koncentrace celkových bílkovin v krevní plazmě $(P<0.05)$ byl zaznamenán již po 3. dávce Rupinu Special. Na základě výsledků provedeného šetření lze doporučit aplikaci Rupin Special pouze ve 4 výjimečně v 6 dávkách, oproti původně doporučovaným 8 dávkám.

\section{Acknowledgements}

This study was supported by projects MSM 6007665809 and MSM 6215712402 awarded by the Ministry of Education, Youth and Sports of the Czech Republic.

\section{References}

ANDERSON DP, JENEY G 1992: Immunostimulants added to injected Aeromonas salmonicida bacterin enhance the defence mechanisms and protection in rainbow trout (Oncorhynchus mykiss). Vet Immunol Immunopathol 34: 379-389

ANONYMUS 2004: Registered Veterinary Medical Products, $831 \mathrm{p}$.

ČERVINKA S, VYKUSOVÁ B, VLADÍK P, SVOBODOVÁ Z, KOLÁŘOVÁ J 1997: Pilot testing a new medicated feed Rupin Special on common carp. Bulletin of Research Institute of Fish Culture and Hydrobiology, Vodňany, Czech Republic, 33: 232-234

GRONDEL JL, GLOUDEMANS AGM, MUISWINKEL WB 1985: The influence of antibiotics on the immune system. II. Modulation of fish leukocyte response in culture. Vet Immunol Immunopathol 9: 251-260

HORÁKOVÁ M, LISCHKE P, GRÜNWALD A 1986: Chemical and physical methods of water analysis. SNTL, Praha, $392 \mathrm{p}$.

HRBÁČEK J, LELLÁK J, STRAS̆KRABA M, PROCHÁZKOVÁ L, KOMÁREK J, DVOŘÁKOVÁ MC, PROKEŠOVÁ V 1962: Hydrobiological methods.. Ed. 2., SPN, Praha, 130 p.

KOLÁŘOVÁ J, NEPEJCHALOVÁ L 2006: Principles and possibilities of treatment in aquacultures in Czech Republic. Veterinářství 56: 31-34

KOU GH 1984: Immunosuppresive effects of oxytetracycline in eel. Effects on agglutinin formation. COA Fish Ser 1: $1-5$

LUNDEN T, MIETTINEN S, LOENNSTROEM LG, LILIUS EM, BYLUND G 1998: Influence of oxytetracycline and oxolinic acid on the immune response of rainbow trout (Oncorhynchus mykiss). Fish Shellfish Immunol 8: 217-230

RIJKERS GT, TEUNISSEN AG, VAN OOSTEROM R, VAN MUISWINKEL WB 1980: The immune system of cyprinid fish. The immunosuppressive effect of the antibiotic oxytetracycline in carp (Cyprinus carpio L.). Aquaculture 19: 177-189

SEREZLI R, CAGIRGAN H, OKUMUS I, AKHAN S, BALTA F 2005: The effect of oxytetracycline on nonspecific immune response in sea bream (Sparus aurata L. 1758). Turk J Vet Anim Sci 29: 31-35

SOLER F, REJA A, GARCÍA-RUBIO L, MÍGUEZ MDP, RONCERO V 1996: Anatomo-pathological effect of oxytetracycline in tench (Tinca tinca). Toxicol Lett 88: 104

SVOBODOVÁ Z, PRAVDA D, PALÁČKOVÁ J 1991: Unified methods of haematological examination of fish. Methods No. 20, Research Institute of Fish Culture and Hydrobiology, Vodňany, Czech Republic, 31 p.

TAFALLA C, NOVOA B, ALVAREZ JM, FIGUERAS A 1999: In vivo and in vitro effect of oxytetracycline treatment on the immune response of turbot, Scopthalmus maximus. J Fish Diseases 22: 271-276

VAN DER HEIJDEN MHT, VAN MUISWINKEL WB, GRONDEL JL, BOON JH 1991: Immunomodulating effects of antibiotics. In: Chemotherapy in Aquaculture: from Tudory to reality symposium. Paris, pp. 219-239 